\title{
ACCRUED FORECASTING ON TOURIST'S ARRIVAL IN BANGLADESH FOR SUSTAINABLE DEVELOPMENT
}

\author{
Sayed Mohibul HOSSEN* \\ Universiti Sains Malaysia, School of Mathematical Sciences, Penang, Malaysia. Mawlana Bashani \\ Science and Technology University, Department of Statistics, Tangail, Bangladesh, e-mail: m300cht@gmail.com
}

Mohd Tahir ISMAIL

Universiti Sains Malaysia, School of Mathematical Sciences, Penang, Malaysia, e-mail: m.tahir@usm.my

Mosab I. TABASH

Al Ain University, College of Business, Al Ain, United Arab Emirates, e-mail: mosab.tabash@aau.ac.ae

\author{
Ahmed ABOUSAMAK \\ Al Ain University, College of Business, United Arab Emirates and Suez Canal University, Egypt, e-mail: Ahmed.AbouSamak@aau.ac.ae
}

\begin{abstract}
Citation: Hossen, S.M., Ismail, T.M., Tabash, M.I,, \& Abousamak, A. (2021). ACCRUED FORECASTING ON TOURIST'S ARRIVAL IN BANGLADESH FOR SUSTAINABLE DEVELOPMENT. GeoJournal of Tourism and Geosites, 36(2spl), 708-714. https://doi.org/10.30892/gtg.362spl19-701
\end{abstract}

\begin{abstract}
Forecasting of potential tourists' appearance could assume a critical role in the tourism industry, arranging at all levels in both the private and public sectors. In this study our aim to build an econometric model to forecast worldwide visitor streams to Bangladesh. For this purpose, the present investigation focuses on univariate Seasonal Autoregressive Integrated Moving Average (SARIMA) modeling. Model choice criteria were Mean Absolute Percentage Error (MAPE), Mean Absolute Error (MAE), and Mean Squared Error (RMSE). As per descriptive statistics, the mean appearances were 207012 and will be 656522 (application) every year. Mean Absolute Deviation and Mean Squared Deviation likewise concurred with MAPE, MAE, and MSE. The result reveals that for sustainable development the SARIMA model is the reasonable model for forecasting universal visitor appearances in Bangladesh.
\end{abstract}

Key words: forecasting; tourist arrival; economic impacts; sustainable development; SARIMA model

\section{INTRODUCTION}

In the 21 st century, the tourism industry has gotten one of the significant and quickest developing areas on the planet (Hassani et al., 2017). It is an assortment of exercises, services, and industries, including the business of food and beverage, transportation, marketing, entertaining, and other accommodation services accommodated people or gatherings (Konarasinghe, 2016). The economic impacts of tourism development are noticeable both in the local and global aspects of the financial sphere. Residents' advantage by the tourism industry over expanded industrial action, upgrade of recreational offices, the revival of local cultures, the opening of eateries, and interests in environmental infrastructure. Besides this, tourist appearances can influence residents' prosperity through genuine experiences (Ivlevs, 2017). The development of the tourism industry business, for the most part, relies upon the growth in the appearances of both local and foreign tourists (Mishra et al., 2018). Their expenditure plays a vital role in the tourism industry and is treated as the foundation of the economic impacts (Smolčić Jurdana and Soldić Frleta, 2017). Revenue from the tourism industry that expands the national income, likewise, fills in as the source of tax revenue for worldwide governments (Tiwari et al., 2018). A range of recreational items motivates tourists, escape from daily life, experience new things, and expand new social relationships (Volchek et al., 2019). Numerous investigations found that individual safety and destination image are additionally the significant determinants of destination decision for guests (Hamadeh and Bassil, 2017). A recent study revealed that tourists are strongly motivated by cultural reasons as well as very interested in realistic features (de Simone et al., 2018). For productive tourism industry businesses, it is critical to react quickly to up and coming interest, in this manner, making constrained resources accessible for co-inventive assistance creation forms. Forecasting on tourism demand can stipulate vital information for successive planning and policymaking (Sun et al., 2019). Therefore, the arrival of tourists prediction is not only essential for business planning, growth strategies, and operations of travel and tourism companies but in measuring and expecting the region's overall economic activity (Bangwayo-Skeete and Skeete, 2015). Moreover, projections of tourist appearances help governments informing medium and long-haul procedures for local and regional tourism industry improvement, planning, and sustainability (Höpken et al., 2018). An acute requirement is needed for the travel industry for minimizing risk, to adjust, and gain by the new opportunity. Therefore, it ought to think about business and destination adaptation of the travel industry that needs to go far and wide emanation modeling and forecasting and mitigation strategies.

\footnotetext{
* Corresponding author
} 
Tourism is a vital industry for developing countries like Bangladesh since it promotes quite a lot to their GDP. Bangladesh is a very well industrialized country and popular as a tourist destination (Lim and Giouvris, 2017). In 2013 the number of arrivals was 277596, while in 2017 this number increased by 778143. Because of the expanding trend, it is significant to conjecture the number of visitor appearances with exactness since it will profit the immediate and circuitous exercises that are identified with the tourism industry. Along these lines, the legislature or related organizations and offices could utilize the projected figure to make an improvement situation, for example, preservation of natural resources and to produce appealing open doors for foreign investors. From the above discussion we can say that in policymaking, marketing, and operation levels, seasonality has a significant role (Liu et al., 2018). By realizing this, the Box-Jenkins technique was applied in this study to build the Seasonal ARIMA model and forecast monthly tourists' arrival in Bangladesh.

\section{Sustainable Tourism Development in Bangladesh}

Tourism that appreciates both residents and the traveler according to cultural heritage and the environment is defined as Sustainable tourism. By providing exciting and educational holiday it makes beneficiary the people of the host country (Chatziantoniou et al., 2016). Impacts that occurred economically, socio-culturally, and environmentally by Sustainable tourism are neither constant nor temporary (Dillimono, 2015). Perceptions of residents' on tourism are affected by the economic, social, cultural, and environmental factors and their willingness to participate in an exchange to support for or against tourism development (Witchayakawin et al., 2020). By creating opportunities Sustainable tourism will take place in a high level of tourism activity of its area for the social, economic, natural, and cultural environment (WTTC, 2019). Based on the above definitions, it is clear that the impact of sustainable tourism on the environment and local culture seems to be an industry. Moreover, it is helpful for residents to create future employment ( $\mathrm{Du}$ and $\mathrm{Ng}, 2018$ ). As a result, it is easy for residents to participate in decision-making, which affects their lives and create a positive impact to protect the natural and cultural heritage. The more present literature on forecasting tourism industry requests has propelled an assortment of new and imaginative quantitative modeling and determining approaches (Apergis et al., 2017). Nonetheless, other than long-haul trends, tourist appearances generally follow occasional stable trends (Wolfram et al., 2017). In Bangladesh, there are lots of ancient mosques, temples, pagoda, shrines, historical and archaeological sites all over the country. Various religious and cultural shows and the ethnic lifestyle of indigenous people of hill tracts are useful forms of cultural diversity that might act as a powerful component of developing sustainable tourism in Bangladesh (Ara Parveen, 2013).

\section{MATERIALS AND METHODS}

\section{Data Collection}

The Tourism demand is generally estimated by the tourism industry incomes or the number of guest appearances. Since monthly data on the tourism industry incomes are not accessible, so we collect tourist's arrival data from Bangladesh Tourism Board (BTB) and Bangladesh Civil Aviation Authority. We use total monthly visitor arrivals to Bangladesh between January 2015 and July 2019. For data analysis, we use the statistical software named Eviews 9. It is especially useful for econometric analysis.

\section{The SARIMA Model}

In the procedure of Autoregressive (AR) with order p, by a weighted normal of past observations, the present remark is created and returning $\mathrm{p}$ periods together with parameters $\phi_{1}, \phi_{2}, \ldots, \phi_{\mathrm{p}}$ in the present time frame with a random disturbance. We mean this procedure as AR (p) and compose the equation (Rahmatullah and Imon, 2017) below,

$$
\mathrm{y}_{\mathrm{t}=\mathrm{c}} \mathrm{c}+\phi_{1} \mathrm{y}_{\mathrm{t}-1}+\phi_{2} \mathrm{y}_{\mathrm{t}-2}+\ldots+\phi_{\mathrm{p}} \mathrm{y}_{\mathrm{t}-\mathrm{p}}+\varepsilon_{\mathrm{t}}
$$

Again, with order $\mathrm{q}$ in the procedure of Moving Average (MA), every observation is created by a prejudiced mean of random disturbance returning to q periods with parameters $\theta_{1}, \theta_{2}, \cdots, \theta_{q}$. We indicate this procedure as MA (q) and compose the equation below,

$$
\mathrm{y}_{\mathrm{t}}=\mu+\varepsilon_{\mathrm{t}}+\theta_{1} \varepsilon_{\mathrm{t}-2}+\ldots+\theta_{\mathrm{q}} \varepsilon_{\mathrm{t}-\mathrm{q}}
$$

With moving average error terms, the mathematical form of Autoregressive schemes are denoted by;

$$
\mathrm{y}_{\mathrm{t}}=\mathrm{c}+\phi_{1} \mathrm{y}_{\mathrm{t}-1}+\phi_{2} \mathrm{y}_{\mathrm{t}-2}+\ldots+\phi_{\mathrm{p}} \mathrm{y}_{\mathrm{t}-\mathrm{p}}+\varepsilon_{\mathrm{t}}+\theta_{1} \varepsilon_{\mathrm{t}-1}+\theta_{2} \varepsilon_{\mathrm{t}-2}+\ldots+\theta_{\mathrm{q}} \varepsilon_{\mathrm{t}-\mathrm{q}}
$$

This technique is named the ARMA procedure of request $(p, q)$ or quickly ARMA (p, q). Time series models accept that it is stationary. In any case, huge numbers of the econometric time series are non-stationary that is incorporated. If a time series is coordinated of order one, i.e., I(1), its first contrasts is $\mathrm{I}(0)$, it means stationary. Correspondingly, if a series is $\mathrm{I}(2)$, its subsequent contrast is $\mathrm{I}(0)$. As a rule, on the off chance that a time series is $\mathrm{I}(\mathrm{d})$, at that point after differencing it ' $\mathrm{d}$ ' times we get I(0) series. Along these lines, the ARIMA (p,d,q) procedure can be composed as,

$$
\Delta^{d} y_{t}=\emptyset_{1} \Delta^{d} y_{t-1}+\cdots+\emptyset_{p} \Delta^{d} y_{t-p}+\varepsilon_{t}+\theta_{1} \varepsilon_{t-1}+\cdots+\theta_{q} \varepsilon_{t-q}
$$

Where, $c$ and $\mu$ are constant $\varepsilon_{\mathrm{t}}$ is assumed to be a normal random variable with 0 mean and variance $\sigma_{\varepsilon^{2}}$

$\mathrm{p}=$ number of autoregressive terms and $q=$ number of moving average terms

$\mathrm{d}=$ number of differencing

$\varepsilon_{\mathrm{t}-1}, \varepsilon_{\mathrm{t}-2}, \ldots, \varepsilon_{\mathrm{t}-\mathrm{q}}=$ errors in previous periods

$\Delta y_{t}=y_{t}-y_{t-1}, \Delta^{d}$ indicates the $\mathrm{d}$ th difference of $y_{t}$ and $\Delta y_{t-1}=y_{t-1}-y_{t-2}$ are the first differences of $y_{t}$ and so on.

And $\Delta^{d}$ indicates the $\mathrm{d}$ th difference of $\mathrm{y}_{\mathrm{t}}$.

On the off chance that the data shows a solid regular example, this demonstrates a relationship between observed values during a similar season in successive years. Considering that the nonseasonal part is (p, d, q) and (P, D, Q)s is the seasonal 
portion, then we can mark Seasonal ARIMA (SARIMA) model as ARIMA (p, d, q) * (P, D, Q)s which could be composed as: $\phi_{\mathrm{p}}(\mathrm{L}) \phi_{\mathrm{p}}^{\mathrm{s}}\left(\mathrm{L}^{\mathrm{s}}\right)$

Where $\phi_{\mathrm{p}}(\mathrm{L}), \theta_{\mathrm{q}}$ are defined earlier, the seasonal period is denoted by $\mathrm{s}$,

$$
\Phi^{\mathrm{s}}\left(\mathrm{L}^{\mathrm{s}}\right)=1-\phi_{1}^{\mathrm{s}} \mathrm{L}^{\mathrm{s}}-\phi_{\mathrm{p}}^{\mathrm{s}} \mathrm{L}^{\mathrm{sP}} \text { and } \theta_{\mathrm{q}}^{\mathrm{s}}\left(\mathrm{L}^{\mathrm{s}}\right)=1+\theta_{\mathrm{q}}^{\mathrm{s}} \mathrm{L}^{\mathrm{s}}+\ldots+\theta_{\mathrm{q}}^{\mathrm{s}} \mathrm{L}^{\mathrm{sQ}}
$$

the number of times is D and the seasonal difference operator (1-L ${ }^{\mathrm{s}}$ ) is applied (Hossen et al., 2021). Building an ARIMA model comprises four orderly stages (identification, estimation, diagnostic check, and application or forecast).

\section{RESULTS AND DISCUSSION \\ Model Identification}

At first, we check the data series, whether it is stationary or not, and show if any seasonality exists. We usually apply different techniques in time series data such as Graphical analysis, Correlogram, and Unit root test to check the stationarity. The most applied method to test a unit root is the Dickey-Fuller (DF), in the parametric context. To check the stationarity, the DF and Augmented Dickey-Fuller (ADF) tests are widely used. However, it is not possible to apply the DF test if the error terms are autocorrelated and there is no trend in the time series. Besides this, we can use two other tests measuring stationarity named Kwiatkowski-Philips-Schmidt-Shin (KPSS) and Phillips-Perron (PP) test. Results from different tests are given in Table 1. By using the Autocorrelation Function (ACF) and Partial Autocorrelation Function we recognize the reasonable (ARIMA) model. The ACF tells us the number of significant autocorrelations in a model which is a valuable gauge of the quantity of Moving Average (MA). Then again, the number of Autoregressive (AR) coefficients can be found from PACF in an ARIMA model.

Table 1. Different test result for stationary (Source: Authors' work)

\begin{tabular}{|l|c|c|c|c|c|}
\hline & \multicolumn{5}{|c|}{ Test results for Stationary } \\
\hline Unit Root test & $\begin{array}{c}\text { test } \\
\text { statistic }\end{array}$ & Prob.* & $\begin{array}{c}1 \% \\
\text { level }\end{array}$ & $\begin{array}{c}5 \% \\
\text { level }\end{array}$ & $\begin{array}{c}10 \% \\
\text { level }\end{array}$ \\
\hline Augmented Dickey-Fuller test & $-5.235^{* \cdots \cdots}$ & 0.0001 & & & \\
\hline $\begin{array}{l}\text { Elliott-Rothenberg-Stock DF- } \\
\text { GLS test }\end{array}$ & -6.034 & & -2.601 & -1.946 & -1.614 \\
\hline Phillips-Perron test statistic & $-8.439^{*-\cdots}$ & 0.0000 & & & \\
\hline $\begin{array}{l}\text { Kwiatkowski- } \\
\text { Phillips-Schmidt-Shin test }\end{array}$ & 0.063 & & 0.739 & 0.463 & 0.347 \\
\hline
\end{tabular}

Table 2. SARIMA model for tourists' arrival

\begin{tabular}{|c|c|c|c|c|c|c|c|}
\hline & & \multicolumn{3}{|c|}{ Model Fit statistics } & & \\
\hline Item & Model & $\begin{array}{c}\text { R- } \\
\text { squared }\end{array}$ & RMSE & MAE & MAPE & $\begin{array}{c}\text { Jarque } \\
\text {-Bera }\end{array}$ & $\begin{array}{c}\text { Prob. } \\
*\end{array}$ \\
\hline $\begin{array}{c}\text { Tourists } \\
\text { arrival }\end{array}$ & $\begin{array}{c}\text { SARIMA } \\
(0,1,1) \\
(0,1,1)_{12}\end{array}$ & 0.48 & 3178.26 & 2864.62 & 12.38 & 0.66 & 0.72 \\
\hline
\end{tabular}

\section{Modelling and Diagnostic Check}

For the presence of seasonality, we build a model called Seasonal Autoregressive Integrated Moving Average (SARIMA) for monthly tourists' arrival in Bangladesh. By applying the model building process of Box-Jenkins (1976) and modified by Box, et al. (2019), we have proposed a SARIMA model. Here the first regular or seasonal differences were taken for model identification. After getting the best SARIMA model, then we check the model using some diagnostic checking such as residual diagnostics and stability tests. The model which shows the lowest mean square error, we choose that model for better forecasting. Our required model for forecasting is shown in Table 2.

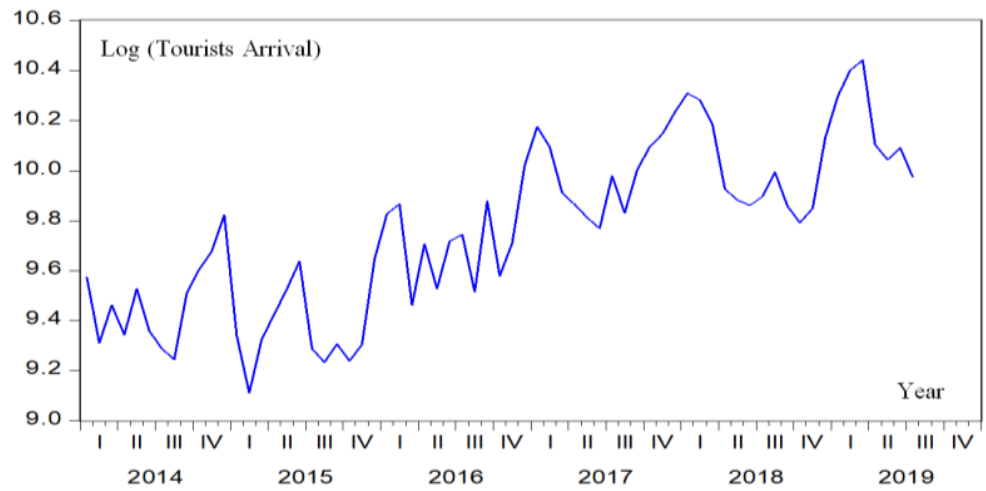

Figure 1. Pattern of data after taking the logarithm (Table-4)

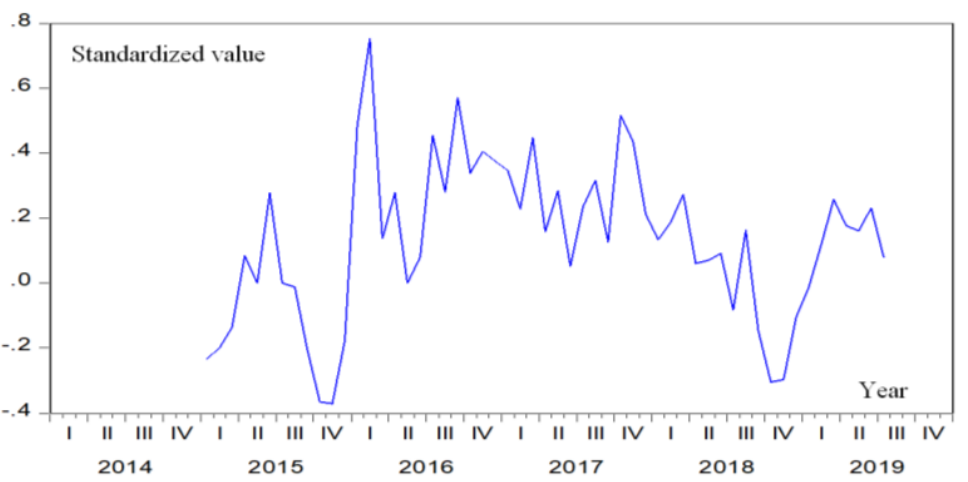

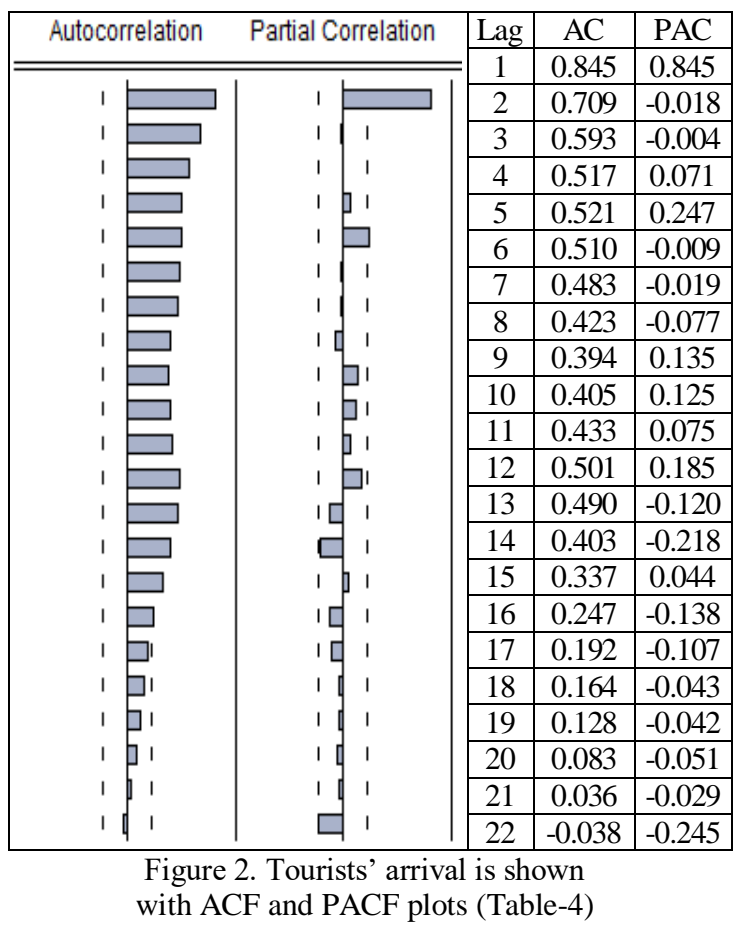

Figure 3. Seasonal difference of the data (Table-5) 
Time series plot of tourists' arrival is shown with ACF and PACF plots

For identifiable model proof, seasonal contrast was taken. In a time series, the arrangement of changes starting with one season then onto the next is named the seasonal contrast. In this study monthly data were collected that contain 12 periods in a season, the regular distinction is $y_{t}-y_{t-12}$ of at period $t$, which is symbolized as $\nabla_{12} y_{t}$, where $\nabla_{12} y_{t}=y_{t}-y_{t-12}$.

The seasonal differenced series from the above Figure 3, show that the series seems to be stationary. Now at different lags our attempt to evaluate Seasonal Autocorrelation (SAC) and Seasonal Partial Autocorrelation (SPAC) $\mathbb{V}_{12} y_{t}$

\section{Correlogram Q-statistics for residual diagnostics checking}

From Figure 4 and 5, it is visible that with exponential decay AR and MA move in opposite directions. Both autocorrelation and partial autocorrelation function show a quick decrease and all the spikes are in standard error bounce after taking the first difference. So, we can conclude that in the time series data the series becomes stationary, and it is an ARIMA model with the presence of seasonality. In the residual, there is no autocorrelation indicated by Autocorrelation and Q-test for different lags. Therefore, the obtained model is stipulated fully.

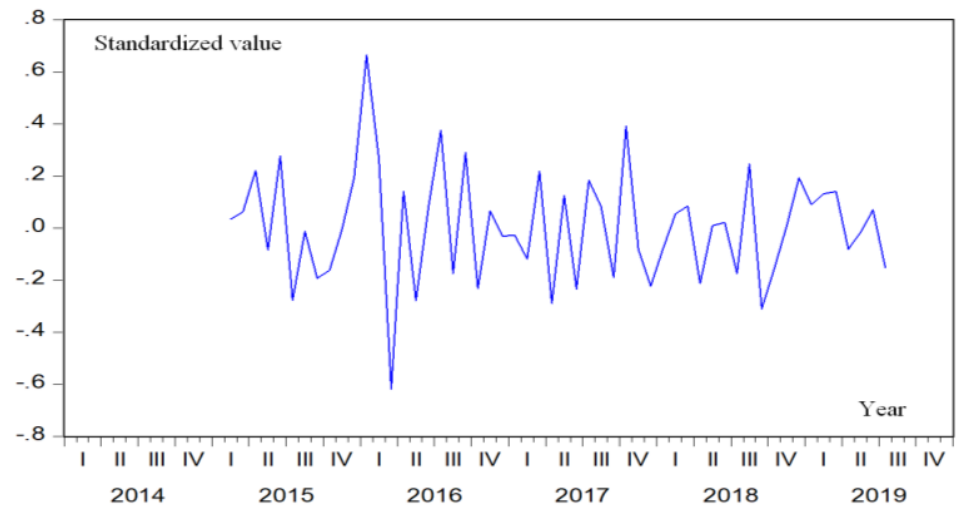

Figure 4. Pattern of data after taking the regular difference (Table-6)

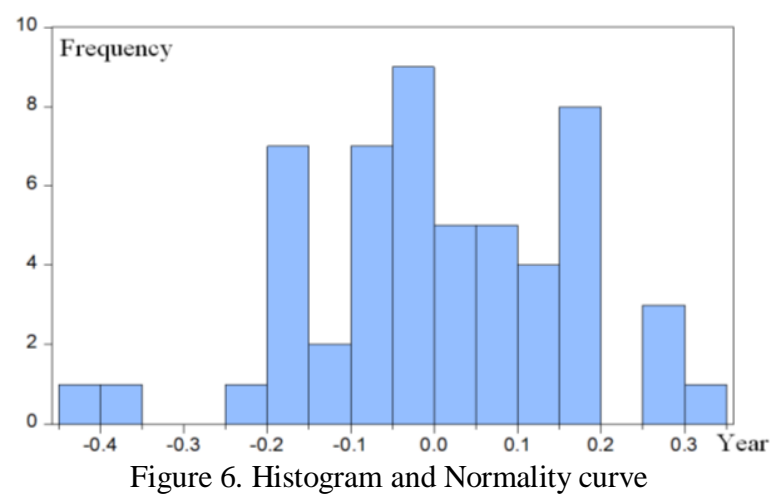

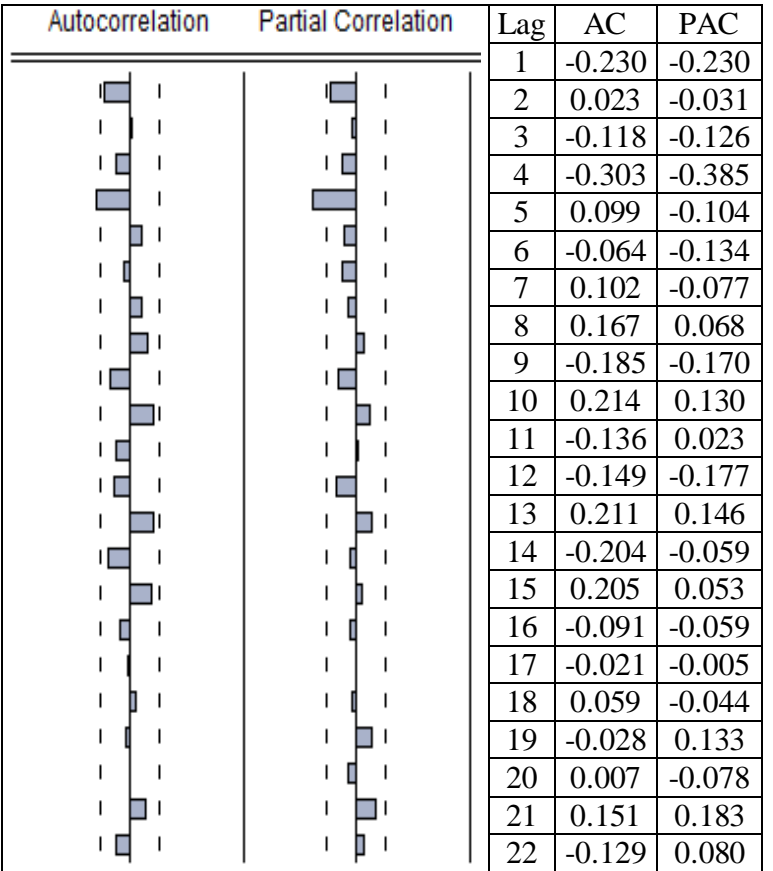

Figure 5. Correlogram for SARIMA $(0,1,1)(0,1,1)_{12}$ model (Table-5)

\section{Histogram and Normality test}

By the Histogram and Normality test, we can decide that residuals are normally distributed or not. For this, our next step is to check the normality of residuals according to the above two techniques. The Jarque-Bera normality test (Table 2) and Figure 6 of histogram and normality curve tell us that the residual is normally distributed. Which indicates that the obtained model is fully stipulated.

\section{Outline checking with actual, fitted, and residual plot \\ Actual fitted and residual plots are shown below:}

Figure 7. Actual fitted and residual plot for SARIMA $(0,1,1)(0,1,1)_{12}$ model (Table-6)

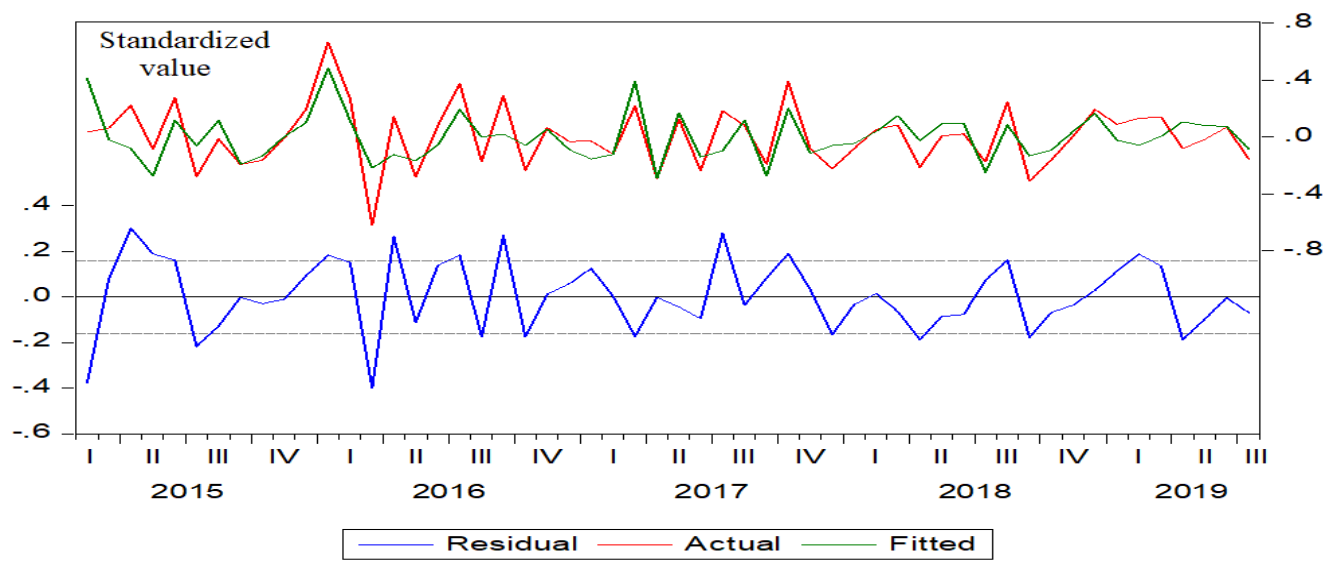

Outline checking for the SARIMA $(0,1,1)(0,1,1)_{12}$ model was checked by a standardized residual plot. A standardized residual plot is shown below: 


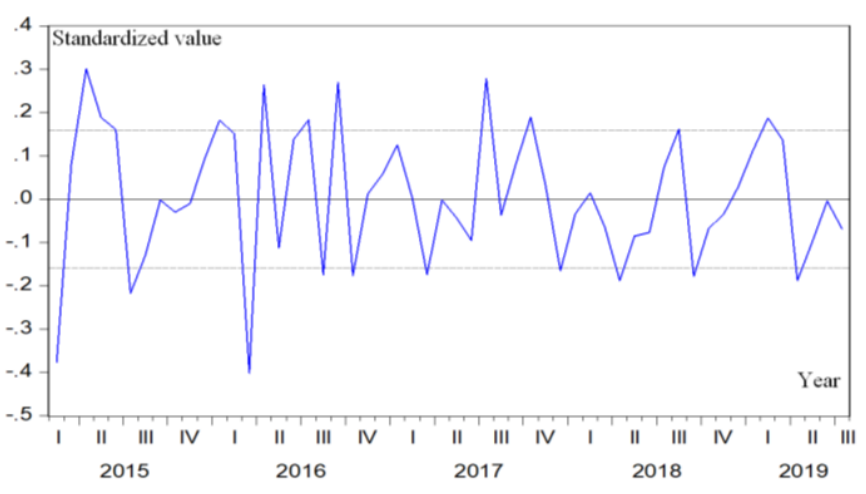

- D(LOG(TOURIST),1,12) Residuals

Figure 8. Standardized residual plot for SARIMA $(0,1,1)(0,1,1)_{12}$ model (Table-6)

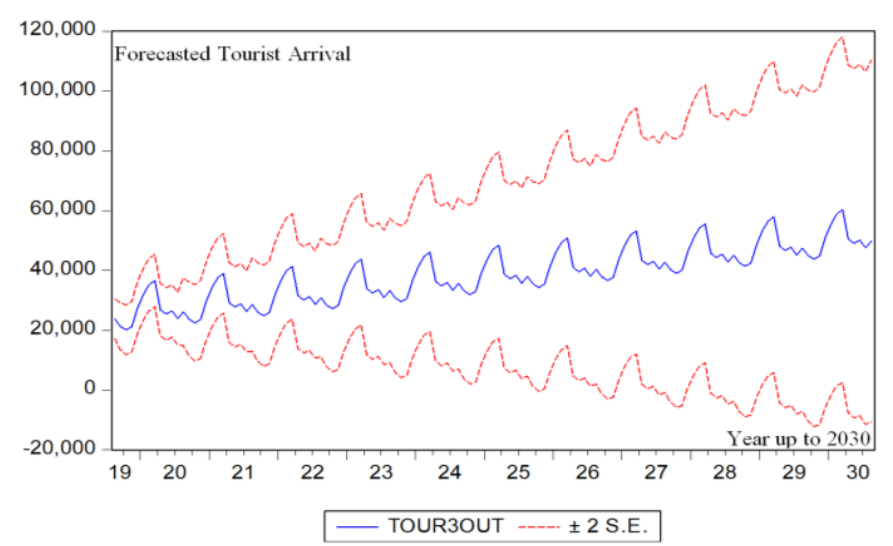

Figure 9. Out sample forecast of tourists' arrival using the SARIMA $(0,1,1)(0,1,1)_{12}$ model (Table-7)

\section{Forecasting of Tourists arrival}

Time series investigation and prediction have become a significant apparatus in various applications in the tourism industry and different tourisms related regions to get marvels, as remote and nearby visitors' appearance, tourist's expenditure, and income from the tourism industry-related areas. We mainly study the time series data to show the forecasting behavior and we aim to fit an appropriate time series model to forecast the fitted model of the tourists' arrival in Bangladesh. Seasonality is present in the time series data; we take the seasonal difference after getting the series stationary. By observing autocorrelation and partial autocorrelation function, we try to fit an appropriate SARIMA model. For monthly tourists' arrival, our fitted SARIMA model is $(0,1,1)(0,1,1)_{12}$ and then we estimate the parameters of the model. By using Residual diagnostics and stability tests we justify the validity of the model after getting the appropriate model. To check the normality in residuals, we apply a normal probability plot and Jarque-Bera test. After that by using the fitted model, we forecast up to 2030.

The ramifications of this outcome are that the SARIMA model is fitted to catch the examples of outside visitor appearances and to forecast the equivalent in Bangladesh with a high accuracy level. The presentation of the SARIMA model might be better because of the consistency and diligence in seasonality in the tourism 1 industry, i.e., the foreign tourist appearances in Bangladesh are most significant in each February and least in each October. Subsequently, the findings of this exploration work can be utilized to figure better development approaches, particularly by the Government for the tourism industry in the nation.

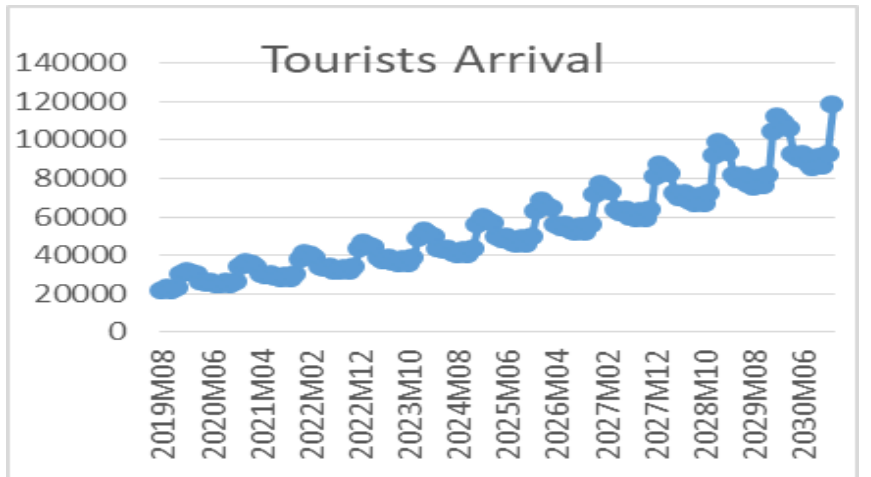

Figure 10. Forecast patterns of tourists' arrival up to the year 2030 (Table-7)

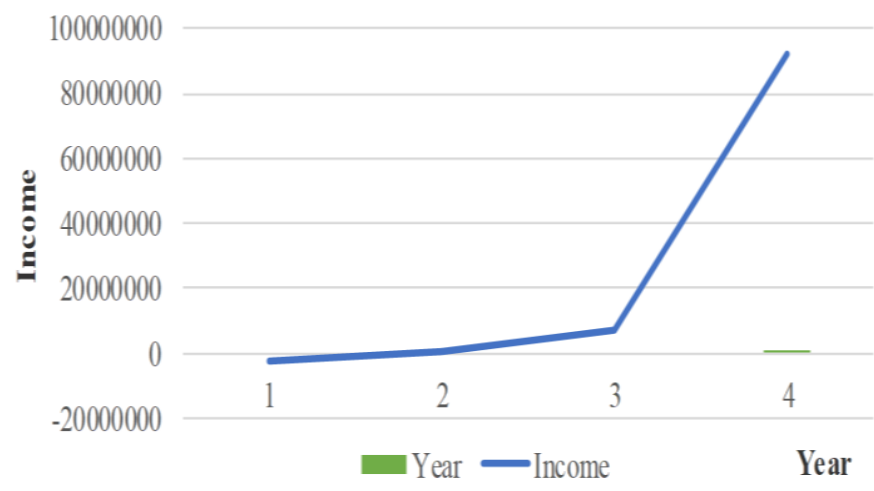

Figure 11. patterns of Income from tourists' arrival in Bangladesh (Bangladesh Parjatan Corporation)
Table-3. Number of tourists arriving from January' 2015 to July'2019 (Source: Bangladesh Tourism Board (BTB) and Bangladesh Civil Aviation Authority)

\begin{tabular}{|l|r|r|r|r|r|r|}
\hline Year/Month & 2014 & 2015 & 2016 & 2017 & 2018 & 2019 \\
\hline January & 14387 & 11387 & 18548 & 26256 & 30025 & 29610 \\
\hline February & 11050 & 9050 & 19254 & 24214 & 29225 & 32887 \\
\hline March & 12868 & 11223 & 12868 & 20142 & 26478 & 34288 \\
\hline April & 11423 & 12428 & 16423 & 19247 & 20458 & 24429 \\
\hline May & 13730 & 13730 & 13730 & 18256 & 19586 & 23018 \\
\hline June & 11604 & 15322 & 16607 & 17485 & 19163 & 24158 \\
\hline July & 10811 & 10811 & 17059 & 21569 & 19856 & 21497 \\
\hline August & 10349 & 10225 & 13550 & 18596 & 21896 & \\
\hline September & 13511 & 11012 & 19511 & 22142 & 19126 & \\
\hline October & 14835 & 10287 & 14451 & 24254 & 17879 & \\
\hline November & 15940 & 10991 & 16496 & 25501 & 18940 & \\
\hline December & 18440 & 15451 & 22498 & 27829 & 25075 & \\
\hline
\end{tabular}

Table-4. Log Transformation of tourists arriving from January '2015 to July'2019 (Modified: 2014M01 2019M12 // T=log(tourist)

\begin{tabular}{|c|c|c|c|c|c|c|}
\hline Year/Month & 2014 & 2015 & 2016 & 2017 & 2018 & 2019 \\
\hline January & 9.574080 & 9.340228 & 9.828117 & 10.17565 & 10.30979 & 10.29587 \\
\hline February & 9.310186 & 9.110520 & 9.865474 & 10.09469 & 10.28278 & 10.40083 \\
\hline March & 9.462499 & 9.325721 & 9.462499 & 9.910562 & 10.18407 & 10.44255 \\
\hline April & 9.343384 & 9.427707 & 9.706438 & 9.865110 & 9.926129 & 10.10353 \\
\hline May & 9.527338 & 9.527338 & 9.527338 & 9.812249 & 9.882570 & 10.04403 \\
\hline June & 9.359105 & 9.637045 & 9.717580 & 9.769099 & 9.860737 & 10.09237 \\
\hline July & 9.288319 & 9.288319 & 9.744433 & 9.979012 & 9.896262 & 9.975669 \\
\hline August & 9.244645 & 9.232591 & 9.514142 & 9.830702 & 9.994059 & \\
\hline September & 9.511259 & 9.306741 & 9.878734 & 10.00523 & 9.858804 & \\
\hline October & 9.604745 & 9.238636 & 9.578519 & 10.09634 & 9.791382 & \\
\hline November & 9.676587 & 9.304832 & 9.710873 & 10.14647 & 9.849031 & \\
\hline December & 9.822277 & 9.645429 & 10.02118 & 10.23383 & 10.12963 & \\
\hline
\end{tabular}




\section{Income from tourists}

In terms of profit, Bangladesh Parjatan Corporation (BPC) is showing its performance well. This Profit is calculated by extracting total expenditure from total income from tourism in a year. Its loss was about -2291443.07 US Dollars, in 20082009. Where 42510340.48 and 44799113.46 US Dollars were the total income and total spending respectively. However, after that, it is showing a notable profit to the national economy. Its gain was 276542.84 US Dollars in 2009-2010 but in 2012-2013 it was 7232536.06 US Dollars which was constantly increased. These amounts have risen to 92421222.01 US Dollars in the year 2017. This can be shown in figure 11.

Table- 5. Seasonal difference of tourists arriving from January

'2015 to July'2019 (Modified: 2014M01 2019M12 // sl=(1-1(-12))

\begin{tabular}{|l|c|c|c|c|c|c|}
\hline Year/Month & 2014 & 2015 & 2016 & 2017 & 2018 & 2019 \\
\hline January & NA & -0.233853 & 0.487890 & 0.347533 & 0.134136 & -0.013918 \\
\hline February & NA & -0.199666 & 0.754954 & 0.229212 & 0.188094 & 0.118053 \\
\hline March & NA & -0.136778 & 0.136778 & 0.448064 & 0.273507 & 0.258481 \\
\hline April & NA & 0.084323 & 0.278731 & 0.158672 & 0.061019 & 0.177397 \\
\hline May & NA & 0.000000 & 0.000000 & 0.284911 & 0.070321 & 0.161461 \\
\hline June & NA & 0.277940 & 0.080535 & 0.051519 & 0.091638 & 0.231634 \\
\hline July & NA & 0.000000 & 0.456114 & 0.234579 & -0.082751 & 0.079407 \\
\hline August & NA & -0.012054 & 0.281551 & 0.316560 & 0.163357 & \\
\hline September & NA & -0.204519 & 0.571993 & 0.126498 & -0.146428 & \\
\hline October & NA & -0.366108 & 0.339883 & 0.517818 & -0.304955 & \\
\hline November & NA & -0.371755 & 0.406041 & 0.435600 & -0.297442 & \\
\hline December & NA & -0.176848 & 0.375753 & 0.212652 & -0.104207 & \\
\hline
\end{tabular}

Table-6. Residuals of tourists arriving from January'2015

to July'2019 (Modified: 2014M01 2019M12 // rsl=(sl-sl(-1))

\begin{tabular}{|l|c|c|c|c|c|c|}
\hline Year/Month & 2014 & 2015 & 2016 & 2017 & 2018 & 2019 \\
\hline January & NA & 0.034187 & 0.267064 & -0.118320 & 0.053958 & 0.131971 \\
\hline February & NA & 0.062887 & -0.618176 & 0.218851 & 0.085413 & 0.140428 \\
\hline March & NA & 0.221101 & 0.141952 & -0.289391 & -0.212488 & -0.081084 \\
\hline April & NA & -0.084323 & -0.278731 & 0.126238 & 0.009302 & -0.015935 \\
\hline May & NA & 0.277940 & 0.080535 & -0.233391 & 0.021317 & 0.070173 \\
\hline June & NA & -0.277940 & 0.375579 & 0.183060 & -0.174389 & -0.152227 \\
\hline July & NA & -0.012054 & -0.174563 & 0.081981 & 0.246108 & 0.131971 \\
\hline August & NA & -0.192464 & 0.290442 & -0.190062 & -0.309785 & \\
\hline September & NA & -0.161590 & -0.232110 & 0.391320 & -0.158527 & \\
\hline October & NA & -0.005647 & 0.066159 & -0.082218 & 0.007513 & \\
\hline November & NA & 0.194906 & -0.030288 & -0.222948 & 0.193234 & \\
\hline December & NA & 0.664738 & -0.028220 & -0.078516 & 0.090289 & \\
\hline
\end{tabular}

\section{CONCLUSION}

Tourist appearance forecast gets troublesome in Bangladesh because of its non-straight pattern. Be that as it may, forecast of Tourist appearance is fundamental for the tourism- industry-related businesses trying to define efficient and effective systems for keeping up and boosting the tourism industry segment. Thinking about the essentialness, in this study SARIMA demonstrating procedure was applied. The R-squared worth (0.48) was found. This shows that the SARIMA models created to forecast Tourist appearance in the present investigation are sensibly exact. Thus, the obtained SARIMA model can be utilized as a handy apparatus for across the country Tourist arrival forecasting. All in all, these findings are significant for the strategy hover taking a shot at the sustainable development of the tourism industry in Bangladesh.

The result of a rising trend in foreign tourist appearances flags the government just as private partners to stay arranged to respect an expanding number of global sightseers in years ahead. The finding of seasonality in Bangladesh tourism the travel industry demonstrates February as the pinnacle month and October as the lean month of every year. This signals the general population just as the private area to stay arranged for confronting a deficiency in limit during pinnacle and abundance limit during lean. To get rid of the issues of seasonality in foreign tourist arrivals, it is fundamental to distinguish, expand, create and advance the tourism industry items, for example, eco-tourism, adventure tourism, rural tourism, sports tourism, and cruise tourism in the nation. These items can guarantee round the year tourists to visits just as rehash visits. Inferable from the expanded flow of visitors from a couple of nations, the system of such reliance could be clarified by the assessment of improved deceivability, feelings, and observations (from a worldwide point of view) about Bangladesh as a tourist destination.

\section{REFERENCES}

Apergis, N., Mervar, A., \& Payne, J.E. (2017). Forecasting disaggregated tourist arrivals in Croatia: Evidence from seasonal univariate time series models. Tourism Economics, 23(1), 78-98. https://doi.org/10.5367/te.2015.0499

Ara Parveen, J. (2013). Current Status of Tourism Industry In Bangladesh: An Empirical Evaluation. Scientific Research Journal (SCIRJ), l(1), 41. www.scirj.org

Bangwayo-Skeete, P.F., \& Skeete, R.W. (2015). Can Google data improve the forecasting performance of tourist arrivals? Mixed-data sampling approach. Tourism Management, 46, 454-464. https://doi.org/10.1016/j.tourman.2014.07.014

Box, G.E.P., \& Jenkins, G.M. (1976). Time Series Analysis, Forecasting and Control. San Francisco, Holden- Day, California, USA. 
Box G.E.P., Gwilym, M.J., Gregory, \& C.R. (2019). Time Series Analysis: Time Series Analysis Forecasting \& Control. New Jersey: Prentice Hall, Englewood Cliffs.

Chatziantoniou, I., Degiannakis, S., Eeckels, B., \& Filis, G. (2016). Forecasting tourist arrivals using origin country macroeconomics. Applied Economics, 48(27), 2571-2585. https://doi.org/10.1080/00036846.2015.1125434

De Simone, E., Canale, R.R., \& Di Maio, A. (2018). Do UNESCO World Heritage Sites Influence International Tourist Arrivals? Evidence from Italian Provincial Data. Social Indicators Research, 146(1), 1-15. https://doi.org/10.1007/s11205-018-1939-7

Dillimono, H.D. (2015). Travel, tourism, climate change, and behavioral change: travelers' perspectives from a developing country, Nigeria. Journal of Sustainable Tourism, 23(3), 437-454. https://doi.org/10.1080/09669582.2014.957212

Du, D., \& Ng, P. (2018). The impact of climate change on tourism economies of Greece, Spain, and Turkey. Environmental Economics and Policy Studies, 20(2), 431-449. https://doi.org/10.1007/s10018-017-0200-y

Hamadeh, M., \& Bassil, C. (2017). Terrorism, war, and volatility in tourist arrivals: The case of Lebanon. Tourism Analysis, 22(4), 537-550. https://doi.org/10.3727/108354217X15023805452086

Hassani, H., Silva, E.S., Antonakakis, N., Filis, G., \& Gupta, R. (2017). Forecasting accuracy evaluation of tourist arrivals. Annals of Tourism Research, 63, 112-127. https://doi.org/10.1016/j.annals.2017.01.008

Höpken, W., Eberle, T., Fuchs, M., \& Lexhagen, M. (2018). Search Engine Traffic as Input for Predicting Tourist Arrivals. Information and Communication Technologies in Tourism, 1, 381-393. https://doi.org/10.1007/978-3-319-72923-7_29

Hossen, S.M., Ismail, M.T., \& Tabash, M.I. (2021). The Impact of Seasonality in Temperature Forecast on Tourist Arrivals in Bangladesh: an Empirical Evidence. GeoJournal of Tourism and Geosites, 34(1), 20-27. https://doi.org/10.30892/gtg.34103-614

Ivlevs, A. (2017). Happy Hosts? International Tourist Arrivals and Residents' Subjective Well-being in Europe. Journal of Travel Research, 56(5), 599-612. https://doi.org/10.1177/0047287516662353

Konarasinghe, K.M.U.B. (2016). Forecasting Tourist Arrivals to Sri Lanka: Post-War Period. 3(1), 57-63.

Lim, S.K., \& Giouvris, E. (2017). Tourist arrivals in Korea: Hallyu as a pull factor. Current Issues in Tourism, O(0), 1-32. https://doi.org/10.1080/13683500.2017.1372391

Liu, H.H., Chang, L.C., Li, C.W., \& Yang, C.H. (2018). Particle swarm optimization-based support vector regression for tourist arrivals forecasting. Computational Intelligence and Neuroscience, 2018. https://doi.org/10.1155/2018/6076475

Mishra, P., Rout, H., \& Pradhan, B. (2018). Seasonality in Tourism and Forecasting Foreign Tourist Arrivals in India. Iranian Journal of Management Studies, 11(4), 629-658. https://doi.org/10.22059/ijms.2018.239718.672776

Rahmatullah, A.H.M., \& Imon, A.H.M. (2017). Introduction to Regression, Time Series and Forecasting. Nandita Prokash, Dhaka, The Bangladesh.

Smolčić Jurdana, D., \& Soldić Frleta, D. (2017). Satisfaction as a determinant of tourist expenditure. Current Issues in Tourism, 20(7), 691704. https://doi.org/10.1080/13683500.2016.1175420

Sun, S., Wei, Y., Tsui, K. L., \& Wang, S. (2019). Forecasting tourist arrivals with machine learning and internet search index. Tourism Management, 70(February 2018), 1-10. https://doi.org/10.1016/j.tourman.2018.07.010

Tiwari, A.K., Dash, A.K., \& Narayanan, B.G. (2018). Foreign tourist arrivals in India from major source countries: an empirical analysis. Current Issues in Tourism, 2l(10), 1137-1156. https://doi.org/10.1080/13683500.2017.1296415

Volchek, K., Liu, A., Song, H., \& Buhalis, D. (2019). Forecasting tourist arrivals at attractions: Search engine empowered methodologies. Tourism Economics, 25(3), 425-447. https://doi.org/10.1177/1354816618811558

Witchayakawin, P., Chantanupan, R., \& Tabash, M.I. (2020). Impacts and benefits from tourism an example from Thailand. Geojournal of Tourism and Geosites, 32(4), 1270-1276. https://doi.org/10.30892/GTG.32412-568

Wolfram, H., Ernesti, D., Fuchs, M., Kronenberg, K., \& Lexhagen, M. (2017). Information and Communication Technologies in Tourism 2017. Information and Communication Technologies in Tourism 2017, 187-199. https://doi.org/10.1007/978-3-319-51168-9

*** WTTC. (2019). Travel \& Tourism: global economic impact. https://www.statista.com/statistics/233223/travel-and-tourism--totaleconomic-contribution-worldwide

*** WTTC. (2019). Travel \& Tourism: global economic impact. https://www.statista.com/statistics/233223/travel-and-tourism--totaleconomic-contribution-worldwide/

Article history: Received: 03.02.2021 Revised: 23.04.2021 Accepted: 18.06.2021 Available online: 30.06 .2021 